\title{
CHEMICAL COMPOSITION AND ANTI-DIABETIC EFFECT OF JATROPHA CURCAS LEAVES EXTRACT ON ALLOXAN-INDUCED DIABETIC ALBINO RATS
}

\author{
Gana James $^{1}$, Yusuf Garba ${ }^{2}$, Salami Jennifer ${ }^{2}$ and Barau Abdulkareem ${ }^{1}$ \\ ${ }^{1}$ Federal College of Education, Department of Agricultural Education, PMB 109, Kontagora, Niger State, Nigeria. \\ ${ }^{2}$ Federal College of Education, Department of Biology, PMB 109, Kontagora, Niger State, Nigeria.
}

https://doi.org/10.35410/IJAEB.2021.5663

\begin{abstract}
Jatropha curcas (Euphorbiaceae) is a multipurpose plant with many explorable attributes and considerable potentials. Different parts of the Jatropha curcas plants are employed in Indian traditional medicine for the treatment of several disorders .This research assessed the chemical compositions of Jatropha curcas leaves extract and hyperglycemic effect of $250 \mathrm{mg} / \mathrm{kg}$ body weight of Jatropha curcas extract in Albino rats. The rats in their fasting states for 12 hours were intraperitoneally injected with Alloxan $(150 \mathrm{mg} / \mathrm{kg}$ body weight) and hyperglycemia was confirmed 48hours later. The weight and fasting blood glucose levels of all rats were determined before the commencement of the experiment. Oral treatment for 21days commenced immediately after confirmation of hyperglycaemia, using ethanol and methanol Jatropha curcas extract. Diabetes was not induced to Group 1 animals and were administered $1 \mathrm{ml}$ of distilled water as negative control, diabetes was induced to rats in group 2, they were given distill water only as positive control. Group 3 were diabetic and were administered $250 \mathrm{mg} / \mathrm{kg}$ body weight of ethanol Jatropha curcas extract. Rats in group 4 were diabetic and were treated with $250 \mathrm{mg} / \mathrm{kg}$ body weight of extract of methanol Jatropha curcas extract. Group 3 showed highest hypoglycemic effect at the end of 21 days. There is also decrease in blood glucose level in group 4 when compared with group 2 which serves as positive control.Results indicate that Jatropha carcus has great anti-hyperglycemic effect in the diabetic rats and could further be used as an alternative for the treatment of diabetes.
\end{abstract}

Keywords: Jatropha curcas, anti-hyperglycaemia, alloxan, ethanolic and methanolic extracts.

\section{INTRODUCTION}

Diabetes mellitus is one of the common endocrine disorders (WHO, 2004). It is expected to affect 54\% of the global population by 2025 from 2010 and 2030; an increase of 69\% is expected in adults in developing countries and a 20\% increase in developed countries (Shawet al., 2010). Diabetes is characterized by hyperglycaemia, defects in reactive oxygen species scavenging enzymes, a high oxidative stress-induced damage to pancreatic beta cells. In diabetic animals, free radicals are rapidly accumulated and cause oxidative stress, which may impair function of the liver and kidney characterized by suppressed anti-oxidative activities and enhanced lipid peroxidation. Diabetes is associated with oxidative stress leading to an increase production of superioxide radical, hydrogen peroxide and hydroxyl radical or a reduction in the antioxidant defense system (Dahecha et al., 2011). 
Vol. 06, No. 05; 2021

ISSN: $2456-8643$

Currently available therapeutic strategies of diabetes include insulin and various oral antidiabetic agents such as biguanids, glucosidase inhibiters and glinides which are used as monotherapy or in combination to achieve better glyceric regulation (Syet al., 2005). The treatment of diseases in the modern system of medicine is only a regulatory mode with devastating side and after effects including severe hypertension and likelihood of brain hemorrhage. Regardless of enormous advances in medical care, alternative therapies such as medical herbs have become popular over the past several years. The challenges posed by diabetes demands a research agenda, which maximizes the prospects of preventing, more effectively treating and curing the disease. Plants used in traditional medicine represent a valuable alternative for the control of the disease. Hence, there is an increasing demand of natural anti-diabetic products by patients to avoid side effects of insulin and oral hyperglycaemic agents (Holman \&Turner, 1991). According to the World Health Organization, there are more than 1200 plants species worldwide used in the treatment of diabetes. The most effective antidiabetes Indian Medicinal plants are Acaciaarabica (Babul), Alliumcepa(Onion), Alliumsativum (Garlic), Azadirachtaindica (Neem), Hibiscusrosasinesis (Curhal), Jatrophacurcas etc. Jatrophacurcas is regarded as a wonder plant because of its numerous attributes. Jatropha is still used as a traditional medicine in India and Africa. The hydroalcoholic and chloroform extract of leaves of Jatropha curcas demonstrated anti diabetic properly at 250 and $500 \mathrm{mg} / \mathrm{kg}$ in a dose dependent manner in alloxan-induced diabetic rats (Patil et al., 2011).

\section{MATERIALS AND METHODS}

\subsection{Extract preparation}

The J. curcasleaves were freshly collected from Bolobolo Riverside in Kontagora, Niger state in August 2018, sorted by removing extraneous materials; the plant was authenticated by Taxonomist in the Department of Biology, Federal College of Education (F.C.E), Kontagora, Niger state. The leaves were rinsed with distilled water without squeezing and shade dried for the period of two (2) weeks. After drying, the plant materials were pounded into powder form using mortar and pestle. The powdered leaves of $(200 \mathrm{~g})$ were soaked in different portions of $70 \%$ ethanol and methanol for 24 hours, centrifuged at $1000 \mathrm{rev} / \mathrm{min}$, extract was filtered using Whatman filter paper. The filtrate was dried using heating mantle and stored in a refrigerator at $4^{0} \mathrm{c}$.

Alloxan monohydrate was prepared by dissolving $50 \mathrm{~g}$ of alloxan monohydrate in $100 \mathrm{ml}$ of normal saline. Other chemicals and reagents used were of basic analytical grades.

\subsection{Animals}

Adult wistar strain albino rats weighing $(120-200 \mathrm{~g})$ wer obtained from Nigeria Trypanosomiasis centre, Kaduna, Kaduna state. The animals were of both sexes and of approximately of the same age, the animals were acclimatized for two (2) weeks housed in ventilated cages and fed with a normal pellet diet and water ad libitum. The food was withdrawn 18-24 hours before the experiment though water was allowed ad libitum. The animals were exposed to alternate 12 hours of darkness and light each, all procedures were performed in the morning according to current guidelines for investigation of experimental pain in conscious animals (Zimmermon, 1983). The protocol was approved by the institution Animal Ethical Committee.

\subsection{Proximate Analysis}


Triplicate determinations were carried out on some portioned samples of the extract for the various phytochemical constituents which was carried out at the Microbiology and Biochemistry Laboratory in the Federal University of Technology, Minna, Niger State.

\subsection{Induction of Diabetes}

After overnight fasting, diabetes was induced by intra-peritoneal injection of alloxan monohydrate dissolved in normal saline, at a dose of $150 \mathrm{mg} / \mathrm{kg}$ body weight. The animals were allowed to drink water. After the development of diabetes; rats having hyperglycemia (blood glucose level above $100 \mathrm{mg} / \mathrm{dL}$ ) were considered as diabetic rats and were included in the research.

\subsection{Experimental design}

The rats were divided into four (4) groups, of six (6) rats each:

Group I: the rats in this group were apparently normal as negative control, they were administered with distill water.

Group II: the rats in this group were diabetic but not treated (positive control) and were administered with distilled water.

Group III: the rats in this group were apparently diabetic rats treated with methanol extract. $(250 \mathrm{mg} / \mathrm{kg})$ per body weight.

Group IV: the animals in this group were diabetic rats treated with ethanol extract $(250 \mathrm{mg} / \mathrm{kg})$ per body weight

2.6 Statistical Analysis: All the results were expressed as means \pm S.D. These results were submitted to one way ANOVA test and when differences existed, means were separated using Waller Duncan's multiple range test at 0.05 significance level.

\section{RESULTS}

Table 1: showing proximate composition of Jatropha curcas leaves

\begin{tabular}{|c|c|c|c|c|c|c|}
\hline & Moisture & Ash & Fat & Fibre & Protein & Carbohydrate \\
\hline $\begin{array}{l}\text { Ethanolic } \\
\text { extract }\end{array}$ & $4.23 \pm 0.01$ & $\begin{array}{ll}2.6 & \pm \\
0.03 & \end{array}$ & $8.82 \pm 0.03$ & $2.42 \pm 0.03$ & $5.95 \pm 0.04$ & $75.3 \pm 0.03$ \\
\hline $\begin{array}{l}\text { Methanol } \\
\text { ic extract }\end{array}$ & $\begin{array}{ll}15.47 & \pm \\
0.08 & \end{array}$ & $\begin{array}{ll}3.6 & \pm \\
0.05 & \end{array}$ & $3.8 \pm 0.14$ & $1.85 \pm 0.02$ & $6.9 \pm 0.05$ & $68.1 \pm 0.008$ \\
\hline
\end{tabular}

Mean + SD of three (3) determinations

Table 2: Mineral composition of ethanolic and methanolic leave extracts of Jatrophacurcas

\begin{tabular}{|c|c|c|c|c|c|c|}
\hline & $\begin{array}{l}\text { Sodium } \\
\text { (Na) }\end{array}$ & $\begin{array}{l}\text { Potassium } \\
\text { (K) }\end{array}$ & $\begin{array}{l}\text { Phosphorous } \\
\text { (P) }\end{array}$ & $\begin{array}{l}\text { Calcium } \\
\text { (ca) }\end{array}$ & Iron $(\mathbf{F e})$ & Zinc (Zn) \\
\hline $\begin{array}{l}\text { Ethanolic } \\
\text { extract }\end{array}$ & $62.4 \pm 0.01$ & $\begin{array}{ll}179.81 & \pm \\
0.01 & \end{array}$ & $4.61 \pm 0.01$ & $\begin{array}{ll}24.91 & \pm \\
0.01 & \end{array}$ & $\begin{array}{l}36.91 \quad \pm \\
0.01\end{array}$ & $\begin{array}{l}1.81 \\
0.01\end{array}$ \\
\hline
\end{tabular}




\begin{tabular}{|c|c|c|c|c|}
\hline $\begin{array}{l}\text { Methanol } \\
\text { extract }\end{array}$ & $\begin{array}{l}62.12 \quad \pm \\
0.02\end{array}$ & $\begin{array}{ll}180.41 & \pm \\
0.01 & \end{array}$ & $16.21 \pm 11.80$ & $\begin{array}{l}24.81 \\
0.01\end{array}$ \\
\hline
\end{tabular}

Table 3: Detected phytochemicals in Jatropha curcas

Detected phytochemicals of the extract

$\begin{array}{ll}\text { Alkaloid } & + \\ \text { Flavonoid } & + \\ \text { Tannin } & + \\ \text { Oxalate } & + \\ \text { Saponins } & +\end{array}$

Note: $(+=$ good quantity)

\subsection{Fasting Blood Glucose Levels (FBG)}

The fasting blood glucose level of normoglycaemic rats were taken before the commencement of the experiment and two (2) days after the induction of diabetes mellitus via alloxan, the fasting blood sugar levels of the rats were taken again as shown in table 4 below to confirm diabetes in the rats. Rats with less than $126 \mathrm{mg} / \mathrm{dl}$ blood sugar levels were excluded from the study. The extracts were administered orally at $250 \mathrm{~m} / \mathrm{kg}$

3.2 Effects of Alloxan induction on normoglycemic rats (48 hours after induction) to confirm hyperglycemia.

Table 4: Changes in glucose levels $(\mathrm{mmol} / \mathrm{L})$ of normoglycaemic rats before and after induction of alloxan as well as a significant reduction of glucose level in the blood after a single dose of the ethanol and methanol extract as compared with the control groups (1\&2).

\begin{tabular}{llll}
\hline $\begin{array}{l}\text { Blood glucose concentration (mmol/L) } \\
\text { Groups }\end{array}$ & $\begin{array}{l}\text { Before induction } \\
\text { Group 1 (negative control) }\end{array}$ & $\begin{array}{l}\text { after induction } \\
\text { no induction }\end{array}$ & $\begin{array}{c}\text { After treatment } \\
4.3 \pm 0.8\end{array}$ \\
Group 2 (positive control) & $6.5 \pm 0.5$ & $10.1 \pm 1.3$ & $13.48 \pm 2.19$ \\
Group 3 (Ethanol Jatropha extract) $5.37 \pm 0.37$ & $9.0 \pm 0.5$ & $7.49 \pm 0.477$ \\
Group 4 (Methanol Jatropha extract) $5.54 \pm 0.77$ & $8.4 \pm 0.8$ & $6.48 \pm 0.998$
\end{tabular}

Values are expressed as Mean \pm SD of 6 rats in each group, is significantly different from the mean values before the induction of alloxan at $\mathrm{P}<0.05$. 
Vol. 06, No. 05; 2021

ISSN: $2456-8643$

\section{DISCUSSION}

Alloxan-induced hypoglycemia occurs when the pancreatic insulin-secreting beta cells are destroyed.Several medicinal plant extracts have been reported to exhibit anti-diabetic activity due to some of their constituted active compounds (Szkudelski, 2001).

The proximate analysis of both ethanol and methanol extracts of Jatropha curcas leaves elucidates the presence of ash, fibre, moisture content, protein and carbohydrate (Table 1) and minerals (Table 2). Also alkaloids, flavonoid, oxalate and saponins were detected too (Table 3). The presence of these vast phytochemicals point to its several ethno medical applications (Igbinosa, 2012) and a potential anti-diabetic agent (Nwamarah et al., 2015). It has been affirmed that medicinal plants with hypoglycaemic and anti-diabetic effect have high concentration of alkaloids and flavonoids (Oladele, 1995).

Rats (group 1) were not induced and were not treated with any of the extracts so their blood glucose remains statistically the same before and after the experiment. Since the rats were randomly selected into groups from population, the statistically constant glycemic value of rats (in group 1) indicated that the rats have normal systemic glucose regulation. Rats (group 2) were induced with diabetes mellitus using alloxan at $150 \mathrm{~m} / \mathrm{kg}$ but they were not treated with any of the extracts i.e. they served as the positive control as there was a dramatic increase in their blood glucose level, due to the effect of alloxan on insulin-producing cell which caused deficiency of insulin and consequently result in hyperglycemia which persisted because the rats (in group 2) were not treated.

The highest reduction of the blood glucose level was observed with the administration of ethanol extract of Jatropha curcasat $250 \mathrm{mg} / \mathrm{kg}$. The result of this anti-hyperglycemic effect of this extract is similar to reports by Mishra et al., (2010), Omale et al., (2011) and Nwamarah et al., (2015).

Also, there is a significant decrease in the blood glucose level after treatment with methanolic Jatropha curcas extract as compared to the positive control group, which is also in line with Momoh et al., 2014, who reported that the methanolic extract possess anti hyperglycaemic, hematopoietic and hepato-protective activities.

The significant decrease in blood sugar level after the periods of 21 days of treatment shows that Jatropha curcas of ethanolic and methanolic extract exhibit a distinct reduction in the blood sugar level of the rats. Some other plants have been reported to have anti-diabetic effects (Latha $\&$ Pari, 2003).

There is no significant difference in blood glucose concentration of group 3 and 4 after treatment but the blood glucose concentration in rats in group 2 were significantly higher than those in group 3 and 4. However, the reduction in blood glucose concentration of rats in group 3 and 4 might be due to differences in concentration of hypoglycaemically active ingredient (s) in Jatrophacurcas leaves.

\section{CONCLUSION}

This study confirmed that physic nut(Jatropha curcas) extract possesses anti-diabetic effect on hyperglycaemic rats. The research also showed that the plant reduced blood glucose at different levels in the rats. These results suggest that Jatropha curcas may provide a new therapeutic avenue against diabetes mellitus, a global burden. It is therefore worthy of further investigation and elucidation to prove its efficacy. 
Vol. 06, No. 05; 2021

ISSN: $2456-8643$

\section{CONFLICT OF INTEREST}

Authors declare that there is no conflict of interest.

\section{REFERENCES}

DahechaI, Belghitha KS, Hamdenb K, Fekib, A, Belghithc, H. Mejdoub, H. 2011.

Antidiabetic activity of levan polysaccharide in alloxan-induced diabetic rats. International Journal of Biological Macromolecules, 49: 742-746.

Holman RR, Turner RC. 1991. Oral agents and insulin in the treatment of NIDDM. In: Pickup J,

Williams G. (Eds). Textbook of Diabetes. Oxford: Blackwell. Pages 467-469.

Igbinosa OO, Igbinosa EO, Aiyegoro OA. 2012. Antimicrobial activity and phytochemical

screening of stem bark extracts from Jatropha curcas (Linn). Afri. Jour. of Pharm. and Pharmaco.3(2):58-62.

Latha M, PariI. 2003. Antihyperglycaemic effect of Cassia auriculata in experimental diabetes and its effect on key metabolic enzymes involved in carbohydrate metabolism. Clin. Exp.

Pharmacol. Physiol. 30:38-43

Mishra SB, Vijayakumar M, Ojha SK, Verma A. 2010. Antidiabetic effect of Jatropha curcas L.leaves extract in normal and alloxan-induced diabetic rats. International general of pharmaceutical sciences 2(1):482-487.

MomohJ, LongeAO, Campbell CA, Omotayo MA. 2014. Evaluation of Antidiabetic and the effect of methanolic leaf extract of Jatropha curcas on some biochemical parameters in alloxan-induced diabetic male albino rats. Euro. Jour. of Medicinal plants,4(12):1501-1512 Nwamarah JU, Otitoju O, Otitoju TO. 2015. Chemical compoisition and anti-diabetic properties of Jatropha curcas leaves extract on alloxan-induced diabetic wistar rats. Afr. Jour. of Biotec., vol 14(12), pp.1056-1066 OladeleSM, Ayo JO, AdaudiAO. 1995. Medicinal and physiological properties of flavonoids, coumarin derivatives and anthraquinones of plants origin. West Afr. J. Pharmacol. Drug Res. 11:134-144.

Omale J, Ebiloma GU, Agbaji AO. 2011. Assessment of biological activities: A comparison of Pergulariadaemia and Jatropha curcas Leaf extracts. Br. Biotecnol.J.1(3):85-100 Patil R,Ahirwar B, Ahirwar D. 2011. Current status of Indian medicinal plants with antidiabetic potential: A Review. Asian Pacific Journal of Tropical Biomedicine, S291-S298.pharmacist,vol. 38 Pp 23-25

Shaw JE, Sicree RA, Zimmet PZ. 2010. Global estimates of the prevalence of diabetes for 2010 and 2030. Diabetes Research and Clinical Practice, 87: 4-14.

Szkudelski T. 2001. The mechanism of Alloxan and Strptozocin action in beat-cells of therats' pancreas. Physiol Res. 50:536-546

Sy GY, Ciss'e A, Nongonierma RB, Sarr M, Mbod NA, Faye B. 2005. Hypoglycaemic and antidiabetic activity of acetonic extract of Vernonia colorata leaves in normoglycaemic and alloxan-induced diabetic rats. Journal of Ethnopharmacology, 98: 171-175.WHO 2004.World Health Organization (http://www.who.org).

Zimmerman M. 1983. Ethical guidelines for investigation of experimental pain in conscious animals. Pain, 16:109-110 